The following is the author's original article, which was published in Mission Studies 33, no. 2 (2016): 127-146. DOI: $10.1163 / 15733831-12341444$

\title{
Emancipatory Intercultural Hermeneutics:
}

\section{Interpreting Theo Sundermeier's Differenzhermeneutik}

\author{
David W. Congdon \\ IVP Academic
}

\begin{abstract}
This article introduces and assesses Sundermeier's "hermeneutic of difference" (Differenzhermeneutik). Though he is not well-known in English-speaking circles, the pioneering work of Theo Sundermeier has contributed to a hermeneutical and intercultural turn within the field of missiology, as well as a missiological and practical turn within hermeneutics. He criticizes the western hermeneutical tradition for being text-centric and egocentric, and he replaces the standard hermeneutical models with one that is focused on the practical problem of understanding the stranger. I summarize the four-step process he provides for learning how to understand and coexist with another person, reflect on its missiological implications, and offer a constructive critique in the direction of a distinctively emancipatory intercultural hermeneutic.
\end{abstract}

Keywords: intercultural theology, hermeneutics, liberation theology, translation, convivencia, praxis 
Broadly defined, intercultural hermeneutics is an interpretive program that locates the process of understanding within the context of intercultural encounter and engagement. The term "intercultural" means "existing between or relating to two or more cultures," and thus, unlike the term "multicultural," the intercultural involves dynamic movement and change with respect to cultural boundaries (Xie 2011:6). The concept of the intercultural thematizes the fluid liminal space between cultures and so carries "the active sense of interaction, confrontation, and even conflict" (Xie 2011:7). Thinking in light of this in-between space has implications for the whole range of intellectual disciplines. Intercultural hermeneutics is just one part, then, of an entire nexus of intercultural discourses, including, among others, intercultural philosophy and intercultural theology. If the pioneers in intercultural philosophy were Franz Martin Wimmer and Ram Adhar Mall, and if the pioneers in intercultural theology were Hans Jochen Margull and Walter Hollenweger, then the pioneer in intercultural hermeneutics is Theo Sundermeier. It is his work that I will introduce and engage critically in this essay.

Sundermeier develops what he calls a hermeneutic of intercultural encounter or intercultural understanding. While it is relevant for the understanding of texts, it is primarily situated in the context of one person understanding another person. For Sundermeier, hermeneutics is fundamentally concerned with mission, with the concrete praxis of the church, which is why the subtitle of his main work on this subject is "a practical hermeneutic" (Sundermeier 1996). "The necessity of a hermeneutic of intercultural understanding" is rooted not in the quest for mere knowledge about what is "exotic" and "other," but rather in "the experience of common life" (Sundermeier 1995b:93). For this reason, the goal of such a hermeneutic is not the interpretation of a text but a "successful life together" (Sundermeier 1996:183). In what follows I will (a) introduce the hermeneutical and intercultural turn within 
missiology, (b) differentiate Sundermeier's "hermeneutic of difference" (Differenzhermeneutik) from other models of understanding the cultural stranger, (c) summarize the essential elements of his hermeneutical model, and (d) present a critical correction of his approach, with its goal of homeostatic communal life, in the direction of a distinctively emancipatory intercultural hermeneutic.

\section{Intercultural Theology and the Hermeneutical Turn}

Intercultural hermeneutics, as practiced by Sundermeier and others, is part of a larger conversation regarding intercultural theology. The rise of intercultural theology over the past few decades constitutes one of the major developments in missiology. Within the German theological academy, there is an ongoing debate about whether to replace "mission studies" (Missionswissenschaft) with "intercultural theology" (interkulturelle Theologie) (Wissenschaftliche Gesellschaft 2008). ${ }^{1}$ According to the German societies for theology and missiology, "the global context necessitates a repositioning of theological thought." Increasing pluralism and globalization present "the ecumenical problem in a new way because[,] locally, Christianity has to interact with regional cultures, milieus and religions." Theology must now have "a special competence in intercultural matters" and must reflect attentively "on the encounters between Christianity and non-Christian religions, worldviews and traditions" (Wissenschaftliche Gesellschaft 2008:104). While Sundermeier does not support the replacement of the discipline of missiology with intercultural theology, his work nevertheless concurs with the claim that the understanding of mission has to change. He calls for a "paradigm shift" in mission studies on the basis of the "new world-situation" and the "latest exegetical insights," the

\footnotetext{
${ }^{1}$ This statement was originally formulated on September 21, 2005. See http://www.dgmw.org/Missionswissenschaft.pdf.
} 
latter being the result of "a more intense listening to the voices of those who live outside of western cultures" (Sundermeier 1995a:79). Since these intercultural encounters necessarily involve one in a process of understanding those who are culturally different, this paradigm shift is essentially a shift from mission as proclamation and evangelism to mission as interpretation and understanding. The new global situation repositions theology as hermeneutics, as the practice of intercultural interpretation. I call this development the "hermeneutical turn" within missiology.

The recognition that mission is fundamentally a matter of interpretation is one of the central contributions of Sundermeier's work. Historically, the problem with missiology is that, by and large, "'hermeneutics' was not a theme of mission studies," since the only question was how to proclaim the message, not how to understand the message itself (Sundermeier 1995b:87). Within this framework missiology was confined to so-called "practical theology," referring to a discipline supposedly concerned only with how to put the content of theology into practice, but not with discerning the content itself, which is traditionally understood as the task of systematic or dogmatic theology. The result of this separation between theory and praxis was that mission was "positioned beyond or outside of the theological disciplines" (Hock 2011:9). The turn to hermeneutics and the rise of intercultural theology is thus a rejection of this artificial bifurcation between theology and mission and a recognition of the "interdependence of text and context" (Sundermeier 1995a:79). The local context of intercultural encounter calls for a fresh understanding of the biblical text and the theological tradition.

Conversely, according to Sundermeier, the problem with the hermeneutical tradition is that it has been insufficiently connected with mission, that is to say, it has not been adequately oriented to the practical concerns of communal life. The classic hermeneutical approach reaches 
its goal in the interpretation of the text, while "the application of the text is a secondary act" (Sundermeier 1996:189). ${ }^{2}$ Theological hermeneutics, he says, is "text-fixated" (81). Moreover, the interpretation itself is individualistic in nature. On this score, above all, Sundermeier seeks to differentiate himself and his program from the practice of modern western hermeneutics, stretching from Schleiermacher to Gadamer:

It is remarkable that in western hermeneutics, particularly in existentialist interpretation, it is always an understanding of myself. It is not the understanding of other persons, of strange texts, but rather of my new self-understanding, produced by the encounter with the text. The other, the stranger, is already in Hegel a roundabout path to myself. ... The conversation that seeks understanding is, in the end, a conversation with oneself. (Sundermeier 1995b:90-91)

Western hermeneutics, according to Sundermeier, promotes an egocentric (not to mention logocentric and text-centric) interpretation that ignores other people and pursues the elimination of differences: "The solipsistic conversation of the self with the words of God is so pervasive that the other person, much less the stranger, is forgotten" (81). He calls the original form of this hermeneutical tradition a "hermeneutic of absorption" (Vereinnahmungshermeneutik), in which the reader seeks "to make the strange text his or her own" (12-13). Gadamer's variation on this tradition is the "hermeneutic of fusion" (Verschmelzungshermeneutik), according to which "understanding has ideally reached its goal if the different perspectives become identical and the horizons fuse together" (13). Either way, the goal is the same: the interpretation of, even mastery over, a text. And the result is the same: what is strange and other is reduced to what is identical and familiar.

For Sundermeier, the problem with modern hermeneutics is that concrete praxis is not seen as being essential to the act of understanding itself. Praxis is confined to the secondary step of "application," while the primary step of interpretation is understood as a process of absorbing

\footnotetext{
${ }^{2}$ Unless otherwise indicated, parenthetical page numbers refer to Sundermeier 1996.
} 
or fusing the text with one's own perspective. Sundermeier overturns this entire hermeneutical approach by making the concrete encounter with the cultural stranger the primary site for interpretation. On this view, interpretation becomes a matter of learning how to live with the stranger and learning how to understand the stranger precisely in her strangeness. Sundermeier thus identifies his approach as a "hermeneutic of difference" (Differenzhermeneutik), which "teaches how to understand what is different without absorbing it, which offers practical help in practicing the proximity of life together, while at the same time preserving the proper distance, by respecting both the identity of the stranger and the human dignity common to us all" (13). ${ }^{3}$

It is important to see that Sundermeier approaches the topic of hermeneutics as a missiologist and not as a textual scholar. He is interested in how we understand strange people, not strange books. This is the key issue that differentiates his hermeneutics from the western hermeneutical tradition, with its emphasis on topics like authorial intention and textual meaning. Sundermeier is not concerned with such questions. For him, the pressing issue of our time is not how we understand what a text means, but how those who live in a pluralistic society understand those who are culturally strange and other. Missiology needs to become hermeneutical not primarily to make better sense of the Bible, but to assist in the project of forming just and peaceful communities.

\section{Four Hermeneutical Models}

\footnotetext{
${ }^{3}$ For more on Sundermeier's Differenzhermeneutik, see Danz 2005, esp. §6.1. According to Danz, Sundermeier's program stands in opposition to the way modern hermeneutics leads "to the absorption, neutralization, or marginalization of the stranger." His alternative is thus "a critical destruction of western hermeneutics" (2005:223-224).
} 
What makes Sundermeier's "hermeneutic of difference" distinct from other kinds of interpretation? In order to answer this question, Sundermeier identifies four different models of understanding the stranger (Fremde).

The first model Sundermeier identifies has been the most common within modernity. He calls it the "model of equality" (Gleichheitsmodell), and it approaches the stranger from the position that all people are equal on the basis that they share a common humanity. Strangeness, in this case, is "negated," since "all human beings are - with the exception of class distinctionsthe same" (73). This model has been leveraged for numerous social ends in the past century and continues to be the fundamental basis for deciding most sociopolitical disputes within democratic, pluralistic countries, given that it purports to be a universal law that transcends cultural and religious differences. Perhaps the most well-known instantiation of it is found in the 1948 Universal Declaration of Human Rights, which begins: "All human beings are born free and equal in dignity and rights." Even where not stated explicitly, "the idea of creation stands in the background of this model" (73). But no matter how "positive the starting point for this model is, its consequences are ambivalent, indeed terrible" (73). And that is because the model precludes any genuine understanding of the other person qua other. Everything depends on determining whether the other person "counts" as a human being. If the stranger is a fellow human, then no understanding is necessary; they are both "the same." If the stranger is "potentially human," then the task is make them human "through religion, through education, through civilization." And if the stranger is not a human being, then he or she can be treated as a "pure object." Whether the stranger is "destroyed or sold as a slave" makes no difference (73).

\footnotetext{
${ }^{4}$ See "The Universal Declaration of Human Rights," accessed July 14, 2014, http://www.un.org/en/documents/udhr.
} 
While this first model has been the basis for advances in social welfare, it has also been the basis for massive devastation throughout the history of western imperialism and colonization.

The second model is the "model of alterity" (Alteritätsmodell) (74). ${ }^{5}$ According to this approach, the stranger is the "wholly other" (ganz andere), a phrase used originally by Rudolf Otto in his book on the idea of the holy and numinous (Otto 1920:29). Sundermeier further alludes to Otto's concept of the mysterium tremendum et fascinans when he says regarding this model: "As a tremendum the stranger is to other people at the same time a faszinosum." The stranger thus elicits "fear and worry," but sometimes "allure and attraction" (74). The stranger is either a terrifying enemy that one flees or an exotic foreigner, who causes one to flee one's own culture to join the stranger. In other words, the model of alterity leads to complete difference or complete identity, and so again there is no actual understanding of the stranger.

The third is the "model of complementarity" (Komplementaritätsmodell). ${ }^{6}$ According to Sundermeier, this is the "prevailing view in the west," from Plato to Husserl (75). On this view the stranger is a complement to the self. This complementary function can take three different forms, each better than the last: (1) the stranger reveals a lack in the self and so, after being appropriated and incorporated, the stranger "completes me"; (2) the stranger is "a detour [Umweg] to myself," a "temporary refuge" on the way toward a strengthening of oneself; (3) self and stranger are bound together in a permanent "togetherness" (Zusammengehörigkeit), as in the I-Thou dialogue of Martin Buber or the alterity ethic of Emmanuel Lévinas (75). The latter two contain promising elements. The second version, exemplified in the encounter with modern art,

\footnotetext{
${ }^{5}$ In a more recent work, Sundermeier calls this the "model of difference" (Differenzmodell), which could lead to some confusion, given that he calls his own proposal, as we have seen, a "hermeneutic of difference" (Sundermeier 2005:82). The word Differenz is, of course, being used here in two different ways.

${ }^{6}$ Sundermeier elsewhere calls this the "model of trade" or "retail model" (Händlermodell), by which he means that "one needs the other, because the other possesses and provides something that one does not produce oneself" (Sundermeier 2005:82).
} 
at least brings one into contact with a different culture, which Sundermeier acknowledges can be the step toward genuine intercultural understanding even though it still remains egocentric in nature. The third version avoids the instrumentalization and expropriation of the stranger, but it still remains trapped within a complementary framework, in which self and other are necessarily united. A complementary approach to the stranger does not adequately respect the cultural differences between two people.

Having surveyed the three standard models for encountering the stranger, Sundermeier presents his alternative, which he calls the "homeostatic" (homöostatische) model of encounter or, in another work, the "dialectical model of strangeness" (dialektisches Fremdheitsmodell) (136; cf. Sundermeier 2005:83). This alternative adheres, he says, to three things: "the identities of the encounterers themselves, their unceasing togetherness, and an interdependence [Aufeinanderangewiesensein] that leads to acknowledgment" (132). The result is a model that is inherently dialectical and paradoxical. It pursues intimacy while recognizing mutual strangeness; it seeks proximity and communion while maintaining a respectful distance. Sundermeier's model simultaneously posits an irreducible strangeness between two persons and their irreducible togetherness. He symbolizes this in a diagram, where a line ("W") both separates two people (" $\mathrm{A}$ " and "B") and constitutes their mutual connection. Without the line, there is neither A nor B, but with the line both A and B are identified as strangers who are nevertheless ineluctably bound together (133). As he puts it, "the quality of one's identity is formed at the boundary of the other" (Sundermeier 2005:83). Each person's identity is actualized as an identity in relation to another, from whom each person is also culturally separated: "Difference and togetherness are here brought to expression as equally original.... The other is neither the alter ego nor the stranger with whom I have no relation. ... The other, who must be specified in this context as 
the stranger, ... is not a contingent accessory of my existence. Strangers are co-constituents in many respects" (133-135). Sundermeier's point in this fourth model is that the two strangers have to be understood as mutually determinative; each determines and constitutes the other, since one's own identity is simultaneously an identity posited in distinction from and in connection with the other person. "Strangeness and identity [Fremdheit und Identität]," he writes, "stand in a relational, interdependent relationship to each other and mutually constitute each other” (Sundermeier 2005:83-84).

Sundermeier thus calls this fourth model a "dialectical" or "homeostatic" model because of the way it preserves a delicate balance between binary extremes. He calls it a "balancing act" between "on the one hand letting the stranger stand in his or her otherness, and on the other hand coming close enough to the stranger that a relationship is possible, which is neither possessive nor dismissive and is able to combine distance with nearness" (Sundermeier 2005:83). The other models fail to maintain this dialectical balance; they instead involve possession, rejection, or a togetherness that does not also sustain the necessary distance. What is needed is a critical distance that can see the other as other and an intercultural openness that can see oneself as bound to that other.

\section{Four Hermeneutical Steps}

Sundermeier's hermeneutic of difference consists of a four-step process. Each of these four steps (Stufen) or levels (Ebenen) involves a subjective attitude, an objective assessment, and an action. He describes these three parts as forming, respectively, a tripartite movement: "going out from oneself, returning to oneself, and an active participation binding both together" (183). The 
following table, adapted from Den Fremden verstehen (155), presents Sundermeier's hermeneutical program and should be read from top to bottom and from left to right:

\begin{tabular}{l|l|l|l} 
& Subjective attitude & Objective assessment & Level of action \\
\hline Level of phenomenon & epoché & descriptive analysis & $\begin{array}{l}\text { perception at a } \\
\text { distance }\end{array}$ \\
\hline Level of sign & sympathy & contextualization & $\begin{array}{l}\text { participatory } \\
\text { observation }\end{array}$ \\
\hline Level of symbol & empathy & $\begin{array}{l}\text { comparative } \\
\text { interpretation }\end{array}$ & (partial) identification \\
\hline Level of relevance & respect & $\begin{array}{l}\text { translation / transfer } \\
\text { to another place }\end{array}$ & convivencia
\end{tabular}

The first step in understanding the stranger is the phenomenal level (Phänomenebene).

This involves encountering the stranger as an object of our perception. The initial subjective attitude is epoché, an ancient Greek term for the suspension of judgment that Sundermeier takes from the transcendental phenomenology of Husserl (158), which here means setting aside prior assumptions so that the stranger can encounter me on her own terms. "The first encounter must be "value-neutral,"” since "each bias," whether negative or positive, "obscures the view" of the stranger (158). Having opened oneself to the other, the objective assessment involves "descriptive analysis." The aim at this stage is simply to describe the phenomenon of the stranger without any subjective involvement or evaluation. This entails deferring any actual interpretation. Hermeneutics begins by resisting the urge to understand the other immediately. One must instead "only register what one sees but not interpret what is seen" (159). Appropriately, the action at this level is "perception at a distance." The distance is highly important, since "one cannot perceive from the position of closest proximity. Proximity constricts the view" (158). One has to see the other for who she is before genuine understanding and intimacy can take place.

The second step is the level of sign (Zeichenebene). Having perceived and described the 
stranger, the second step seeks to understand the stranger in her particular sociocultural context. The task is to observe and interpret the stranger's distinctive cultural marks or signs. "In order not to fall into the trap of schematization and falsifying labels," it is crucial that, in this second hermeneutical step, "we learn to read strange signs" (160-161). Sundermeier here borrows from the field of semiotics, since semiotics "has taught us to pay attention to the signs of the sensible presence of a culture. Language, gestures, clothes, rules of conduct are boundary markers [Grenzzeichen]" (160). These signs or markers simultaneously reveal the identity of a group and demarcate it from others, since "distinction and identity belong together" (159). Sundermeier cautions against moving too quickly past this stage:

The signs must first be read in their own context and must not be hastily translated into our own and incorporated with our logos. Whoever wants to understand the stranger must get involved in the other culture and religion, in order to learn what their signs mean for them and what they want to say to outsiders. . . In order to understand [the stranger], one must enter into the other culture. (162)

The necessary subjective attitude for entering into another culture is sympathy, according to Sundermeier, meaning that one comes alongside the other to "feel-with" (sun-pathos) her. "Sympathy involves a readiness to learn, to understand others in their context, to keep their signs of identity in their context and not to rashly interpret them according to one's own customs, much less to universalize one's own experiences" (161). The objective assessment is therefore contextualization, while the corresponding action, which brings together the subjective and objective elements, is participatory observation. The aim at this stage is to acknowledge, affirm, and understand the stranger's strangeness.

The third step is the level of symbol (Symbolebene). The move from sign to symbol indicates a deeper level of participation and engagement with the stranger, which also entails greater complexity. "While the sign is unique and must say precisely what it wants to say (cf. 
road signs), symbols oscillate, are ambiguous, and can be perceived and interpreted differently by different observers" (166-167). Given this ambiguity, true understanding requires that we empathetically "identify with the strange culture and religion" (168-169). The goal here is to "feel-in" (en-pathos) the stranger, so that I identify her situation as my own. But such identification must not become absorption or fusion. Empathy means that "the stranger must be endured as strange" (170). As Margaret Kornfeld writes, "To be empathic, we must acknowledge that, initially, we don't know the other" (Kornfeld 1998:52-53). Despite the empathetic identification, "there will always be a wall between [oneself] and the stranger" that we cannot and should not remove (169). The task of comparative interpretation (vergleichende Interpretation) consequently involves a gradual or incremental rapprochement between self and stranger that carefully balances both "difference and agreement," since any hasty attempt at rapport with the other "can lead to a deep misunderstanding" (170). This is why the action at this stage is "(partial) identification," with the qualification serving to prevent a rush towards finalizing our understanding of the other. The process of hermeneutical understanding of the other involves an ongoing dialectic of agreement and difference, unity and separation, convergence and divergence. As an example of a cultural symbol that demands this kind of cautious, dialectical engagement, Sundermeier refers to the hijab worn by Islamic women, which has been the source of controversy in France. While the hijab is often seen as a "symbol of oppression" in the modern west, many women embrace it "as a protest against the western lifestyle's cult of the body and sex. In this case wearing a headscarf is precisely not a sign of oppression, but should be viewed, on the contrary, as a symbol of self-determination and freedom." We see, in this example, "a symbol with widely varying meanings" (171-172). It is only after confronting the ambiguity, diversity, and irreducible otherness of the stranger that we 
are in a position to move to the fourth and final step.

The fourth step, the "goal" of the hermeneutical process, Sundermeier calls the "level of relevance" (Relevanzebene) and the "level of pure action" (reine Handlungsebene) (183). This is because there is no longer any theoretical or observational element; each aspect of this fourth step is directly relevant to the task of interacting with the stranger-respect, translation (Übersetzung), and convivencia (Konvivenz). We will look at these in order.

Sundermeier begins by defining the concept of respect, which he juxtaposes to the Hegelian notion of "acknowledgment" or "recognition" (Anerkennung). Recognition places one in relation to another on the basis of the "equality and equal treatment" (Gleichheit und Gleichstellung) of all persons (184). But acknowledgment alone is not enough; it would remain within the first of the hermeneutical models above, the model of equality. For this reason, acknowledgment has to be paired with respect. Whereas acknowledgment focuses on the objective legal-moral aspect of relating to the stranger - and so forms the basic structure of a pluralistic society — respect is a subjective category that pertains to how we see others in our everyday life. Respect does not simply see a legal equal but rather a wonder-inducing other, whose very otherness elicits our respect.

Respect still knows astonishment [Erstaunen] about the other and the stranger. . . . Wonder [Staunen] is the mother of philosophy, say the Greeks. Astonishment, however, is the ground of hermeneutics. In astonishment I am open to the low, the unsightly, and discover otherness, beauty, diversity. The one who is astonished can calmly endure dissonances and does not rashly seek after harmony, for this dissonance belongs to the full sound of life. (184-185) 
Sundermeier here draws on a musical metaphor that compares respect for the stranger to the appreciation for unresolved dissonance, as in, for instance, the atonal or twelve-tone music of twentieth-century contemporary music. ${ }^{7}$

Corresponding to the subjective attitude of respect is the objective task of translation. Sundermeier introduces this aspect by speaking about a hypothetical ethnologist who returns from the field and must translate what she has learned from the work of description, contextualization, and interpretation back into the categories and concepts native to her own context. This act of translation or transference is central to intercultural understanding, since "understanding means being able to name. Only that which can be and is reproduced [wiedergegeben] in one's own language sticks in one's mind and is communicable" (187). The process of "reproducing" what one has encountered in the alien text or strange person involves searching for corresponding words and structures in one's language and culture. The act of translation, of course, is not a benignly neutral deed, since translation is always interpretation within a particular context, and thus the process of "reproducing" is always also a "recreating" (Neuschaffung) and even a "reshaping" (Neugestaltung) $(187,188)$. Interpretation-whether of a historical object or a cultural person—never accesses the "thing-in-itself," so to speak, but only the object or reality as it appears to us, as it becomes meaningful to us through personal encounter. And "like every intense cultural encounter," Sundermeier says, "translation necessarily involves moments of syncretism" (Sundermeier 2005:88). Translation is "not the transporting of cargo unchanged from one shore to another. New pictures, new idioms, new comparisons must be found, which transfer the subject-matter in such a way that it can be

\footnotetext{
${ }^{7}$ The concept of polyphony, popularized by Dietrich Bonhoeffer in his prison writings, does not go far enough, since it pertains to sounds that are inherently harmonious, rather than dissonant. Polyphony thematizes difference but not the strangeness essential to understanding the cultural other. See Bonhoeffer 2010: 393-94, 397.
} 
received on the other shore" (Sundermeier 2005:85). ${ }^{8}$ Coming to grips with this fact, especially in the context of understanding a strange person as opposed to a strange text, involves acknowledging the irreducible differences between oneself and another that translation can never overcome:

The same concepts, the same words, change due to different contexts. . . This must not only be accepted but has to be seen as belonging to the process of understanding, which draws attention to the fact that the understanding of the stranger is and can be always only a partial understanding. There are only approximations in this process of understanding, so it never comes to an end but always opens up new perspectives. (188)

In contrast to a Gadamerian horizon-fusing hermeneutic, a "xenological hermeneutic" (or "hermeneutic of difference") maintains the disparity, the cultural gap, between the two persons, which ensures that the understanding of the stranger remains a modest, provisional affair (188). More importantly, in contrast to "classical text-oriented hermeneutics," the purpose of translation within his practical hermeneutic is not to understand the meaning of a text but to understand how to live with other people. Translation forms a shared field of communication between culturally foreign persons. By translating “the experience with the strange culture into one's own conceptuality" and by searching for "parallel structures, analogies, comparable signs, and identical symbols," one makes possible the true goal of intercultural hermeneutics: shared life together (190).

This brings us, finally, to the goal of Sundermeier's hermeneutic of difference: convivencia (Konvivenz). Sundermeier takes the concept of convivencia from the liberation theology of Latin American base communities, ${ }^{9}$ though he learned what it means through his

\footnotetext{
${ }^{8}$ Sundermeier connects the notion of finding new pictures and concepts with the figure of the stranger: "The stranger indicates that new . . . experiences are necessary" (Sundermeier 1995b:99).

${ }^{9}$ For an example of its use within that context, see volume 2 of Boff 2005.
} 
time in Africa (190). The concept refers, as its etymology suggests, ${ }^{10}$ to the idea of living together with others, specifically with those who are culturally and religiously different. Sundermeier introduced the concept into missiology in a 1986 study, where he argued that convivencia must become the "basic structure of ecumenical existence today" (Sundermeier 1986:52-59; cf. Ustorf 2008:239). Sundermeier defines the ecumenical community of convivencia as a "helping community," a "learning community," and a "festive community" (190-191; cf. Sundermeier 1995a:84). This threefold form of communal life is the goal of intercultural hermeneutics, he says, in the sense that it is both made possible by this hermeneutic and in turn becomes the source for further understanding. Convivencia thus becomes "a spirally progressing process of understanding"-moving from encounter to convivencia, and from convivencia to ever new encounters (191).

An intercultural praxis shaped by convivencia has significant implications for the missionary task. Mission is no longer a process of converting the other to oneself, turning the one who thinks differently into one who thinks the same. Mission understood along these lines would fall into one of the previously rejected hermeneutical models, perhaps the model of equality or the model of complementarity. A hermeneutical model of strangeness, which pursues a shared life with those who are culturally other, overturns the Christendom conception of mission as a unidirectional movement of fixed content from the missionary to the recipient for the purpose of conforming the recipient to the cultural norms of the missionary. As David Bosch observes, "missionaries ... no longer participate as the ones who have all the answers but are learners like everybody else. ... Inculturation only becomes possible if all practice convivência, 'life together"” (Bosch 1991:453). Convivencia becomes "the hermeneutical place in which mission

\footnotetext{
${ }^{10}$ The Latin convivere, which literally means "to live with," has the meaning of feasting together at a party or banquet.
} 
occurs as the understanding of the stranger" (Wrogemann 1997:305). Intercultural mission is thus a sending into places of plurality and dissonance for the purpose of learning to empathize with and respect the stranger. Within this context of shared life together, the entire senderreceiver model becomes obsolete, since "the receiver as hearer of the message is not an object of the sender, not even just an object of the message, but is at the same time the subject and corresponding sender" (Sundermeier 1995b:89). Instead of a unilateral sending and proselytizing, mission within an intercultural framework involves multilateral dialogue for the sake of forming new communities that provide space for genuine difference. The goal of mission, on this view, is ecumenical heterogeneity, not cultural-religious homogeneity. The church would thus become the place for a "creative convivencia" (Sundermeier 2005:112) and "creative pluralism" empowered by the Spiritum sanctum vivificantem, in which "everyone hears and freely responds to the word of reconciliation in their own language, in their horizon of thought, and in their social condition" (Sundermeier 2005:29).

Sundermeier calls this fourth and final step in the process of understanding the level of relevance, because it is "directly relevant in dealing with strange neighbors," as in, for example, "the upstairs tenant who is identified as culturally other. The goal of an intercultural hermeneutic is a successful living-together, in which everyone can remain themselves, no one is co-opted, and yet there still occurs an exchange that respects and strengthens the dignity of others" (183). Interpretation thus reaches its goal when people learn to understand and care for each other.

\section{Emancipating Intercultural Hermeneutics}

Sundermeier's Differenzhermeneutik has plenty to offer the church in a pluralistic society. There is much to appreciate about his vision of mission as the formation of communities of mutual 
understanding. Having said that, it is hard to avoid the impression that his vision of convivencia, despite arising out of the context of liberation theology, lacks the socially emancipatory character of such theology. While his "homeostatic" model provides a helpful framework for respecting each person's distinctiveness and dignity, the idea of homeostasis suggests that the ultimate goal is a pluralistic community marked by a stable social equilibrium, where each person models the democratic virtues of empathy and respect for those who are culturally different. This implies, however, that any disequilibrium can be blamed on some person who has failed to genuinely understand the stranger. One almost gets the impression at times that, within this model, two strangers meet in a kind of vacuum: each has his or her cultural framework and social condition, but there is little attention to the material, political structures and dynamics that can, inter alia, render equilibrium impossible or inappropriate, distort or preclude our understanding of the stranger, or even occlude the stranger altogether by rendering certain persons socially invisible. Sundermeier's call for a respectful coexistence with others is important but overly vague and abstract. His model fails to thematize the concrete socioeconomic factors that create systems of instability and inequity. What does convivencia entail in situations where oppression and injustice threaten the stranger? What does coexistence with the "upstairs tenant" look like when that stranger is systematically marginalized in ways that may even be working to one's own benefit?

It is not as if Sundermeier is unfamiliar with these questions. Some of his earliest work is on black consciousness and black theology. In 1973 he edited the volume Christus, der schwarze Befreier (Christ, the black liberator). His introduction to the volume analyzes black theology in the United States and South Africa, exploring the implications of black consciousness for hermeneutics, christology, and reconciliation. Black theology, he says, does not belong in the 
theological disciplines of systematics or exegesis, but rather in hermeneutics. "Black theology has a hermeneutical function," in the sense that it has an "apologetic-missionary" orientation (Sundermeier 1973:19). It interprets Christian faith according to a concrete experience of the world. Black theology is thus a continuation of and a challenge to traditional Christian theology. Against the either-or of integration or separation - anticipating Sundermeier's later rejection of a binary opposition between sameness and difference-reconciliation within South African black theology is concerned with liberation, which Sundermeier understands as "acceptance" (Annahme) of the other, as a group and as an individual (Sundermeier 1973:27). Embracing this means that white people

cease to observe a kind of guardianship, but instead they learn to listen, to listen and listen again; they learn to accept without judgment; they learn to empathize with the black situation and with black people, and under their leadership ... they travel the path into suffering. ... They must learn to deny their whiteness as much as they can and to abandon their participation in the establishment as far as this is at all possible and legally allowed, and wherever and whenever possible to show solidarity with black Christians. White people are, in a word, called upon to love and suffer with them, even at the risk of being abused. That is a lot, but ultimately it is always the core of every missionary existence. (Sundermeier 1973:32)

We see in this passage many of the themes that will later form Sundermeier's hermeneutic of difference: participation, empathy, and coexistence. At the same time, the emphasis is on interpersonal relationships; he focuses on listening to others and empathizing with their plight, even sharing in their suffering. The systemic factors involved in such relationships, however, seem either ignored or taken for granted. While he speaks about the "establishment" as the cause of suffering, he suggests that a white person should "abandon" the establishment — though only as far as this is "legally allowed"-as if it were a simple matter of personal choice whether one participates in the establishment (i.e., whiteness) or not. The global socioeconomic structures that constitute and reinforce this establishment are left unexamined 
both here and in his later program of intercultural hermeneutics. One explanation for this might be that Sundermeier orients his analysis of black theology around the concept of black consciousness, which leads to a focus on understanding and accepting this consciousness as far as this is possible. But this implies that the concern for liberation is limited to those who share this consciousness, when the truth is that the problem of the establishment transects racial and ethnic boundaries. As noteworthy and commendable as Sundermeier's work on black theology is, there is a need today to move from a missionary existence to an emancipatory existence, and this requires a corresponding emancipatory hermeneutic.

Minimally, an emancipatory intercultural hermeneutic would have to involve an "intercultural praxis," which recognizes that cultures are "complex, complicated, contradictory, multiple, and multileveled locations of speaking/acting/producing/distributing and consuming" (Collier 2014:8). Cultures are far more than signs and symbols. They include "spaces of struggle and contested spaces of relation," and thus to enter into an empathetic relation with the marginalized cultural other necessarily means entering into her struggle for recognition and liberation (Collier 2014:9). Sundermeier gestures in this direction in the above passage, but we now need to take it further. The factors involved in the relation between person A and person B are not merely local and interpersonal; they are also global and social. It is not enough to see the visible phenomenon of the stranger. We must also learn to see the invisible nexus of socioeconomic forces that perpetuate a violent regime of subjugation and suppression, forces that “we ourselves render invisible ... despite our best intentions" (McGarrah Sharp 2013:141). Sympathy and empathy for one another means recognizing the ways we have been conscripted into this regime as agents of oppression, while the level of "pure action" means generating 
counterdiscursive practices that restore agency to those who have been marginalized and silenced by imperial power.

A hermeneutic of difference in this context involves much more than just translating signs and symbols into a different cultural idiom; it requires translating personal narratives into communal action. To understand the stranger is thus to understand the systemic factors that condition our existence and to struggle against them by countering those factors with creative practices that redistribute power and resources toward those who have been denied access, so that they, in turn, can become agents of emancipation for others. As Kathryn Sorrells puts it, "social justice includes a vision of the equitable distribution of resources where social actors experience agency with and responsibility for others" (Sorrells 2013:228). Facilitating this distribution will require "co-authoring potential space" for mutual recognition and empowerment, spaces of creative convivencia where strangers can hear each other's stories and establish bonds of solidarity and active resistance (McGarrah Sharp 2013:154). Intercultural interpretation must ultimately take the form of a liberative praxis that "seeks to disrupt relationships of domination by developing new forms of internationalist understanding and communication" (Heaney 2014:31). The goal of an emancipatory intercultural hermeneutic — that is, a hermeneutic that recognizes the marginalization of the stranger and joins the stranger in her pursuit of liberation - is not homeostasis but revolution, not a pluralistic society but the beloved community. Consequently, intercultural hermeneutics has to be carried out in partnership with political theology and postcolonial theory, among other discourses. The task of understanding the other will require delving into the kinds of concrete economic and political dynamics that Sundermeier largely overlooks. 
Part of the reason behind this omission may be that Sundermeier has in mind the encounter between white Europeans and, say, Namibians, as was the case in his own life. In that situation, the white European or North American has to be especially vigilant against what Teju Cole calls the "White-Savior Industrial Complex," which leads a well-intentioned person to swoop unilaterally into a situation and attempt to "make a difference." But as Cole observes, 'there is much more to doing good work than 'making a difference.' There is the principle of first do no harm. There is the idea that those who are being helped ought to be consulted over the matters that concern them" (Cole 2012). Sundermeier's hermeneutic, which ends with respectful coexistence, aims to preclude this kind of paternalistic action, which is often ethnocentric and imperialistic. Indeed, when Bosch introduces the concept of convivencia, he prefaces it by saying: "Missionaries no longer go with a kind of Peace Corps mentality for the purpose of 'doing good"' (Bosch 1991:453). While the vast majority of intercultural encounters are not transnational, transoceanic confrontations, the Peace Corps image provides a helpful metaphor for what intercultural hermeneutics seeks to avoid. In this sense, Sundermeier's conscientious attention to the danger of co-opting the stranger is itself emancipatory in nature, albeit in a negative sense. His entire hermeneutical program is designed to preclude any violation of the stranger, no matter how good the intentions may be.

Our options, of course, are not restricted to pluralistic homeostasis or violent co-optation. Understanding the stranger in the complexity of her political existence certainly calls for empathy and convivencia, but it may also require something more - a positive emancipatory action - that Sundermeier does not explore. To be sure, this action will always mean listening to her story, as well as to her community's story, and not forcing her or them to fit into a predetermined explanatory framework. The right of the stranger to define her need and the nature 
of her liberation must be preserved. The pure action of translation and convivencia may thus involve channeling resources to local individuals and groups to assist them in their own emancipatory struggle. Empathy and understanding in such situations would require understanding their goals and partnering in their efforts. In the end, even where this savior complex does present a concern and one has to maintain a certain respectful distance, there still remains the need to include assessment of invisible, systemic factors in the descriptive analysis of the other.

For all these reasons, intercultural hermeneutics needs to become an emancipatory intercultural hermeneutics, one that promotes the common struggle for empowerment and liberation in the midst of oppressive economic and political regimes. Doing so would remain faithful to the essence of Sundermeier's program; it would merely expand the scope of what it means to "understand" the stranger. Sympathy (feeling-with) has to become synergy (workingwith), and empathy (feeling-in) has to become energy (working-in). Understanding each other involves collaborating with each other in a dynamic, kinetic movement of persons for the sake of sociocultural transformation. Affirming the pluralism of Sundermeier's vision for convivencia does not mean affirming every aspect of what makes people in the community different or other. Some of those differences — such as class distinctions enforced by oppressive economic policies and unjust social biases — should not be celebrated, and their acknowledgment has to involve some kind of collective action in response.

An emancipatory reworking of Sundermeier's program would also expand the scope of what we mean by mission. Intercultural hermeneutics already expands the scope by defining mission as understanding the other as opposed to converting the other. An emancipatory hermeneutic would reintroduce a more active and goal-oriented dimension to mission, but 
instead of viewing the stranger as the object of mission, the stranger now becomes the partner-

more accurately, the missionary becomes the partner of the stranger-in the collective pursuit of liberation for the community. Understanding the stranger within the context of emancipatory struggle therefore involves identifying with and participating in the stranger's mission, as opposed to including the stranger within our mission. Paradoxically, the missionary task involves our conversion to the needs and demands of the oppressed neighbor. Such a conversion would not entail the abandonment of the cultural differences between the two persons but rather the recognition that, in the midst of such differences, mutual participation in emancipatory struggle is both possible and necessary.

\section{References}

Boff, Leonardo (2005). Virtudes para um outro mundo possivel. 3 vols. Rio de Janeiro: Vozes. Bonhoeffer, Dietrich (2010). Letters and Papers from Prison. Edited by John W. De Gruchy. Trans. by Isabel Best, Lisa E. Dahill, Reinhard Krauss, et al. Dietrich Bonhoeffer Works 8. Minneapolis: Fortress Press.

Bosch, David J. (1991). Transforming Mission: Paradigm Shifts in Theology of Mission. Maryknoll, NY: Orbis.

Cole, Teju (2012). “The White-Savior Industrial Complex.” The Atlantic. 21 March. http://www.theatlantic.com/international/archive/2012/03/the-white-savior-industrialcomplex/254843/.

Collier, Mary Jane (2014). “Critical Community Engagement and Dancing with Cultural Difference: Analytical Framework and Research Itinerary.” In Mary Jane Collier (ed.), 
Community Engagement and Intercultural Praxis: Dancing with Difference in Diverse Contexts. New York: Peter Lang, 1-30.

Danz, Christian (2005). Einführung in die Theologie der Religionen. Wien: Lit.

Heaney, Robert S. (2014). “Prospects and Problems for Evangelical Postcolonialisms.” In Kay Higuera Smith, Jayachitra Lalitha, and L. Daniel Hawk (eds.), Evangelical Postcolonial Conversations: Global Awakenings in Theology and Praxis. Downers Grove, IL: IVP Academic, 29-42.

Hock, Klaus (2011). Einführung in die Interkulturelle Theologie. Darmstadt: WBG.

Kornfeld, Margaret Zipse (1998). Cultivating Wholeness: A Guide to Care and Counseling in Faith Communities. New York: Continuum.

Küster, Volker, ed. (1995). Konvivenz und Differenz: Studien zu einer verstehenden Missionswissenschaft. Erlangen: Verlag der Evangelisch-Lutherischen Mission.

McGarrah Sharp, Melinda A. (2013). Misunderstanding Stories: Toward a Postcolonial Pastoral Theology. Eugene, OR: Pickwick.

Otto, Rudolf (1920). Das Heilige: Über das Irrationale in der Idee des Göttlichen und sein Verhältnis zum Rationalen. 4th ed. Breslau: Trewendt und Granier.

Sorrells, Kathryn (2013). Intercultural Communication: Globalization and Social Justice. Thousand Oaks, CA: SAGE.

Sundermeier, Theo (1973). “Schwarzes Bewusstsein—Schwarze Theologie.” In Theo Sundermeier (ed.), Christus, der schwarze Befreier. Erlangen: Verlag der EvangelischLutherischen Mission, 9-36. 
(1986). “Konvivenz als Grundstruktur ökumenischer Existenz heute.” In Wolfgang

Huber, Dietrich Ritschl, and Theo Sundermeier, Ökumenische Existenz heute 1.

München: Kaiser, 49-100.

(1995a). "Begegnung mit dem Fremden: Plädoyer für eine verstehende

Missionswissenschaft.” In Küster, Volker (1995): 76-86.

— (1995b). “Erwägungen zu einer Hermeneutik interkulturellen Verstehens.” In Küster,

Volker (1995): 87-101.

(1996). Den Fremden verstehen: Eine praktische Hermeneutik. Göttingen: Vandenhoeck

\& Ruprecht.

- (2005). Mission - Geschenk der Freiheit: Bausteine für eine Theologie der Mission.

Frankfurt am Main: Lembeck.

Ustorf, Werner (2008). "The Cultural Origins of 'Intercultural Theology." Mission Studies

XXV, 2: 229-251.

Wissenschaftliche Gesellschaft für Theologie and Deutsche Gesellschaft für

Missionswissenschaft (2008). "Mission Studies as Intercultural Theology and Its

Relationship to Religious Studies.” Mission Studies XXV, 1: 103-108.

Wrogemann, Henning (1997). Mission und Religion in der systematischen Theologie der

Gegenwart: Das Missionsverständnis deutschsprachiger protestantischer Dogmatiker im 20. Jahrhundert. Göttingen: Vandenhoeck \& Ruprecht.

Xie, Ming (2011). Conditions of Comparison: Reflections on Comparative Intercultural Inquiry.

New York: Continuum. 